\title{
Vibrio fortis sp. nov. and Vibrio hepatarius sp. nov., isolated from aquatic animals and the marine environment
}

Correspondence

F. L. Thompson

Fabiano.Thompson@ugent.be

\author{
F. L. Thompson, ${ }^{1,2}$ C. C. Thompson, ${ }^{1,2}$ B. Hoste, ${ }^{2}$ K. Vandemeulebroecke, ${ }^{2}$ \\ M. Gullian ${ }^{3}$ and J. Swings ${ }^{1,2}$ \\ 1,2 Laboratory for Microbiology ${ }^{1}$ and BCCM/LMG Bacteria Collection ${ }^{2}$, Ghent University, K. L. \\ Ledeganckstraat 35, Ghent 9000, Belgium \\ ${ }^{3}$ National Center for Marine and Aquaculture Research, Guayaquil, Ecuador
}

\begin{abstract}
In this study, the taxonomic positions of 19 Vibrio isolates disclosed in a previous study were evaluated. Phylogenetic analysis based on $16 \mathrm{~S}$ rDNA sequences partitioned these isolates into groups that were closely related (98.8-99.1\% similarity) to Vibrio pelagius and Vibrio xuii, respectively. DNA-DNA hybridization experiments further showed that these groups had $<70 \%$ similarity to other Vibrio species. Two novel Vibrio species are proposed to accommodate these groups: Vibrio fortis sp. nov. (type strain, LMG $21557^{\top}=$ CAIM $629^{\top}$ ) and Vibrio hepatarius sp. nov. (type strain, LMG $20362^{\top}=$ CAIM $693^{\top}$ ). The DNA G + C content of both novel species is $45.6 \mathrm{~mol} \%$. Useful phenotypic features for discriminating $V$. fortis and $V$. hepatarius from other Vibrio species include production of indole and acetoin, utilization of cellobiose, fermentation of amygdalin, melibiose and mannitol, $\beta$-galactosidase and tryptophan deaminase activities and fatty acid composition.
\end{abstract}

\section{INTRODUCTION}

Vibrios are among the most abundant culturable microbes in aquatic environments (Heidelberg et al., 2002a). A recent study of the bacterioplankton of Chesapeake Bay showed that Vibrio and Photobacterium species comprised up to $4 \%\left(2 \times 10^{8}\right.$ cells $\left.^{-1}\right)$ of total bacteria (Heidelberg et al., 2002a). High Vibrio and Photobacterium numbers $(4 \cdot 3 \times$ $10^{6} \mathrm{~mm}^{-2}$ ) were also reported to be attached to the external surface of zooplankton. It was concluded that a close partnership exists between these bacteria and zooplankton (Heidelberg et al., 2002b; Lipp et al., 2002). Vibrios also belong to the normal microflora of the shrimp Litopenaeus vannamei (Vandenberghe et al., 1999). Moss et al. (2000) reported that Vibrio and Aeromonas species comprised up to $85 \%$ [about $10^{9}$ c.f.u. (g gut tissue) ${ }^{-1}$ ] of bacterial flora in the gut of this shrimp, whereas Gomez-Gil et al. (1998) found a high abundance of vibrios $\left(10^{5}\right.$ c.f.u. $\mathrm{g}^{-1}$ and $10^{4}$ c.f.u. $\mathrm{ml}^{-1}$, respectively) in the hepatopancreas and

Published online ahead of print on 28 February 2003 as DOI 10.1099/ ijs.0.02658-0.

Abbreviations: FAFLP, fluorescent amplified fragment length polymorphism; FAME, fatty acid methyl ester.

The GenBank/EMBL/DDBJ accession numbers for the 16S rDNA sequences of strains LMG $21557^{\top}$ and LMG $20362^{\top}$ are AJ514916 and AJ345063, respectively.

Tables of variable features among strains of $V$. fortis and $V$. hepatarius are available as supplementary material in IJSEM Online. haemolymph of healthy L. vannamei. Certain Vibrio strains have been reported to be potential probiotics for this shrimp (Gomez-Gil et al., 1998, 2000, 2002). Use of probiotics, i.e. live micro-organisms that, when administered in adequate amounts, confer a health benefit on the host, has been reported to reduce the need for medication (e.g. antibiotics and pesticides) and water exchange, which are used massively in intensive shrimp-rearing (Verschuere et al., 2000).

We have demonstrated that the genus Vibrio harbours a wealth of diverse genomes and represents cosmopolitan and endemic species that are yet to be described (Thompson et al., 2001). The exact ecological role of several of these groups is unknown at present. In this study, we report the taxonomic characterization of FAFLP (fluorescent amplified fragment length polymorphism) clusters A9, A26 and A60 that were disclosed in a former study (Thompson et al., 2001). Group A9 $(n=8)$ was found to be ubiquitous in the marine environment and was associated with both diseased and healthy aquatic animals. Group A26 consisted of three isolates that originated from the hepatopancreas of wild healthy adults of L. vannamei from Ecuador. Recent results suggest that these isolates may have probiotic properties for L. vannamei under culture conditions (M. Gullian \& J. Rodriguez, unpublished data). A representative Vibrio strain, LMG $20362^{\mathrm{T}}$, showed high levels of colonization in the hepatopancreas of L. vannamei and out-competed and excluded the shrimp pathogen Vibrio harveyi. Additionally, 
this strain seems to enhance the health and weight of shrimps (M. Gullian \& J. Rodriguez, unpublished data). Group A60 $(n=8)$ was restricted to cultures of bivalve larvae (Nodipecten nodosus) in south Brazil. We propose to accommodate isolates of groups A9 and A60 in a novel Vibrio species, Vibrio fortis sp. nov., and isolates of group A26 in another novel species, Vibrio hepatarius sp. nov.

\section{METHODS}

Bacterial strains, growth conditions and DNA isolation. Strains characterized in this study are listed in Table 1. Strains were grown aerobically on tryptone soy agar (TSA; Oxoid) supplemented with $2 \%(\mathrm{w} / \mathrm{v}) \mathrm{NaCl}$ for $24 \mathrm{~h}$ at $28^{\circ} \mathrm{C}$. DNA was extracted by following the methodology described by Pitcher et al. (1989). All strains included in this study have been deposited in the BCCM/ LMG Bacteria Collection at Ghent University, Belgium, and in the CAIM collection of the Centre for Research on Nutrition and Development (CIAD) in Mazatlán, Mexico.

Genotypic analyses. Determination of almost-complete 16S rDNA sequences was accomplished essentially as described previously (Thompson et al., 2001). Alignment of $16 \mathrm{~S}$ rDNA sequences, distance estimations (Jukes \& Cantor, 1969), clustering by the neighbour-joining (Saitou \& Nei, 1987), maximum-likelihood and maximum-parsimony methods and calculation of cluster stability (bootstrap analysis with 1000 replicates) were performed with BioNumerics 2.5 software (Applied Maths). DNA-DNA hybridization experiments with photobiotin-labelled DNA were run under stringent conditions $\left(39^{\circ} \mathrm{C}\right)$ following the methodology described by Willems et al. (2001). Hybridizations were performed in four replicates. DNA binding values are means of reciprocal and non-reciprocal reactions. The DNA $\mathrm{G}+\mathrm{C}$ content (mol\%) was determined by HPLC (Mesbah et al., 1989).

Phenotypic analyses. Phenotypic characterization of the isolates was performed by using API 20E and API ZYM kits (bioMérieux) and Biolog GN metabolic fingerprinting, following the instructions of the manufacturers with slight modifications (Thompson et al., 2002). Classical phenotypic tests were performed as described previously (Baumann et al., 1984; Farmer \& Hickman-Brenner, 1992; Vandamme et al., 1998; Thompson et al., 2002). Antibiograms were determined by using the disc-diffusion method (Acar \& Goldstein, 1996) with commercial discs (Oxoid). The inhibition zone of each antibiotic was measured with strains grown on Iso-Sensitest agar (Oxoid) supplemented with $1.5 \%$ (w/v) $\mathrm{NaCl}$ for $24 \mathrm{~h}$ at $28^{\circ} \mathrm{C}$. Fatty acid methyl ester (FAME) analysis was carried out as described by Huys et al. (2001). Isolates were grown on Trypticase Soy Broth (Becton Dickinson) supplemented with $1.5 \%$ (w/v) Bacto agar (Becton Dickinson) and $1.5 \%(\mathrm{w} / \mathrm{v}) \mathrm{NaCl}$.

\section{RESULTS AND DISCUSSION}

The phylogenetic positions of five strains representative of $V$. fortis, LMG $21557^{\mathrm{T}}$ (GenBank/EMBL accession no. AJ514916), LMG 21558 (AJ514913), LMG 20547 (AJ316202), LMG 21566 (AJ514917) and LMG 21562 (AJ514915), from FAFLP groups A9 and A60, were analysed by means of their $16 \mathrm{~S}$ rDNA sequences. These isolates had nearly identical 16S rDNA sequences (Fig. 1) and their closest neighbour was Vibrio pelagius CECT $4202^{\mathrm{T}}$ (AJ293802) with $98 \cdot 8 \%$ sequence similarity. When the $V$. pelagius sequence of Ruimi et al. (1994) was used, i.e. X74722, similarity between the five novel isolates and $V$. pelagius dropped to

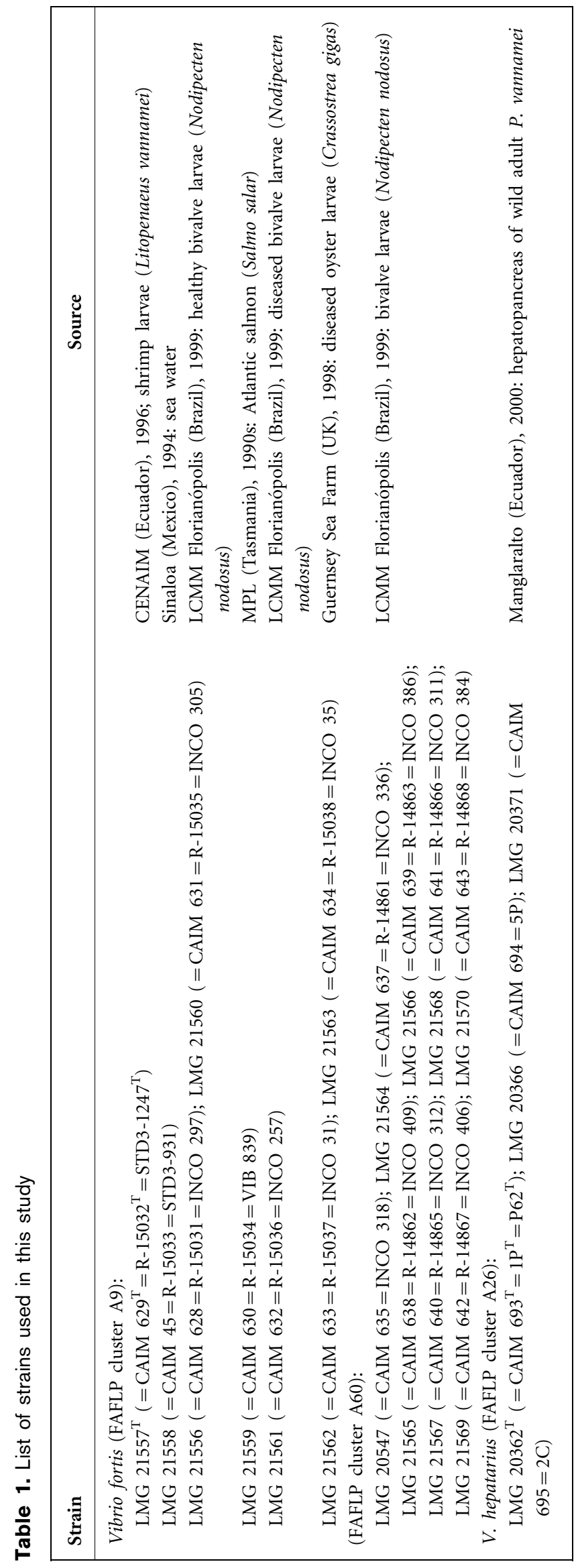




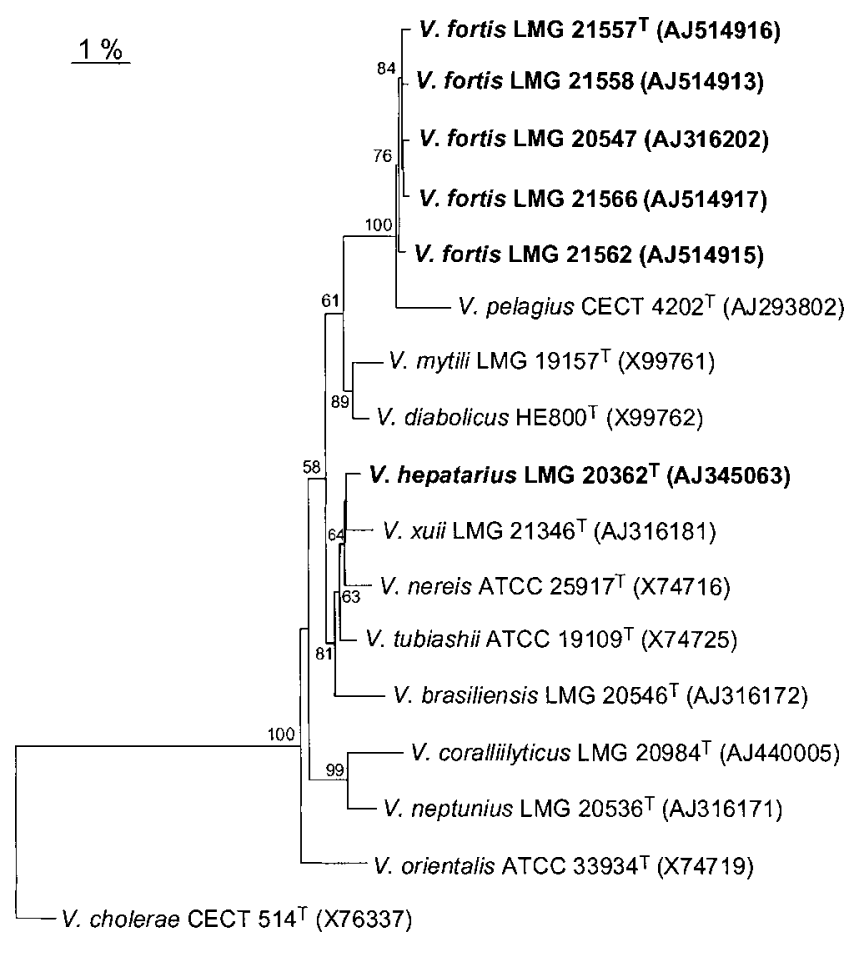

Fig. 1. Phylogenetic tree showing the positions of $V$. fortis and $V$. hepatarius, estimated by using the neighbour-joining method and based on almost-complete 16S rDNA sequences. Bootstrap values $(>50 \%)$ after 1000 simulations are shown. Bar, $1 \%$ estimated sequence divergence.
97·4\%. Macián et al. (2000) have already suggested that the latter GenBank/EMBL entry is most probably a sequence of Vibrio natriegens, rather than $V$. pelagius. Other phylogenetic neighbours of $V$. fortis, with a maximum of $97 \cdot 8 \%$ similarity, are shown in Fig. 1. Vibrio cholerae, Vibrio mimicus and Vibrio metschnikovii were the most distant phylogenetic relatives of $V$. fortis within the genus Vibrio, with 92.5-92.9\% similarity. $V$. hepatarius LMG $20362^{\mathrm{T}}$ was most closely related to the recently described species Vibrio xuii (99.1\% similarity) (Thompson et al., 2003) and to Vibrio tubiashii and Vibrio nereis (98-6-99.0\%) (Fig. 1). $V$. hepatarius was also related to Vibrio mytili, Vibrio diabolicus and Vibrio orientalis (98.0-98.2\%) and its most distant relatives within the genus Vibrio were $V$. mimicus and Vibrio salmonicida $(92 \cdot 9 \%)$.

Results of DNA-DNA hybridization experiments are summarized in Table 2. We chose four representative isolates from cluster A9, as this group was found to be very heterogeneous by FAFLP analysis, and two representative isolates from group A60, which was a very tight FAFLP cluster (Thompson et al., 2001). These six V. fortis isolates formed a single novel species with at least $70 \%$ DNA-DNA similarity, and a maximum of $66 \%$ similarity towards $V$. pelagius. V. hepatarius LMG $20362^{\mathrm{T}}$ had a maximum of $66 \%$ similarity towards $V$. orientalis. Both novel species had $<45 \%$ DNA-DNA similarity to the recently described species Vibrio coralliilyticus (Ben-Haim et al., 2003) and to Vibrio neptunius, Vibrio brasiliensis and V. xuii (Thompson et al., 2003). These results corroborate

Table 2. DNA-DNA binding values and DNA G+C contents of Vibrio strains examined

Taxa: 1, V. fortis LMG $21557^{\mathrm{T}}$; 2, V. fortis LMG 21558; 3, V. fortis LMG 21562; 4, V. fortis LMG 21561; 5, V. fortis LMG 20547; 6, V. fortis

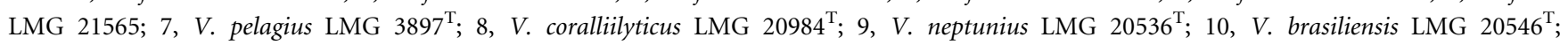
11, V. xuii LMG 21346 ${ }^{\mathrm{T}}$; 12, V. hepatarius LMG 20362 ; 13, V. diabolicus LMG $19805^{\mathrm{T}}$; 14, V. tubiashii LMG 10936 ; 15, V. nereis LMG $3895^{\mathrm{T}}$; 16, V. orientalis LMG $7897^{\mathrm{T}}$; 17, V. mytili LMG $19157^{\mathrm{T}}$.

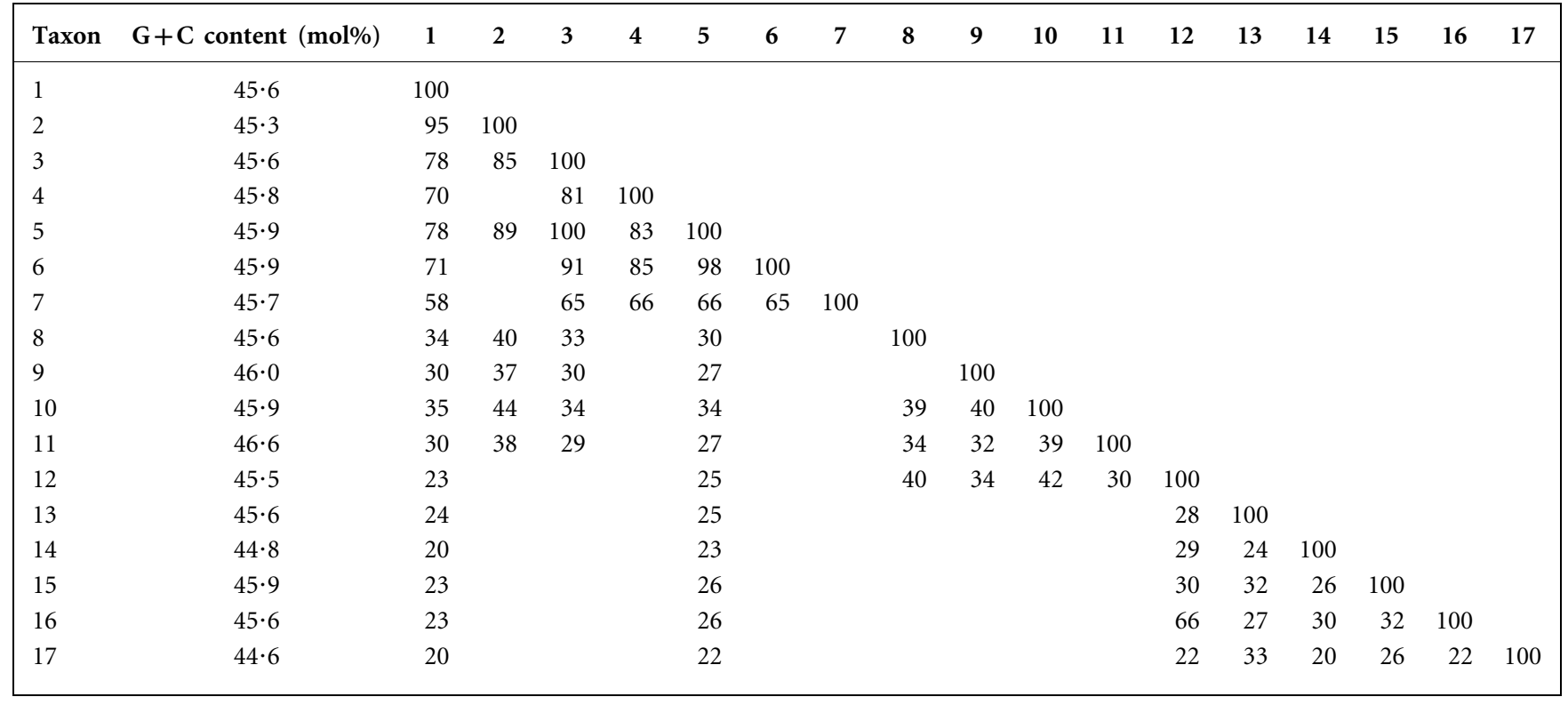


those of our previous FAFLP fingerprinting experiments, which suggested that groups A9, A26 and A60 were novel species within the genus Vibrio (Thompson et al., 2001).

Both novel Vibrio species represented by the 19 isolates examined in this study shared the main phenotypic and chemotaxonomic features of the genus Vibrio (Lambert et al., 1983; Farmer \& Hickman-Brenner, 1992; Bertone et al., 1996). They were facultatively anaerobic, oxidasepositive and showed prolific growth on thiosulfate/citrate/ bile salts/sucrose agar (TCBS). Isolates were slightly curved rods, motile, susceptible to vibriostatic agent O/129 (except for LMG 21568 and LMG 21559) and their growth was stimulated by $\mathrm{NaCl}$. In spite of their similarity to other Vibrio species, the two novel species showed several differentiating phenotypic features (Table 3 ). We therefore propose to accommodate A9 and A60 isolates in a novel species, $V$. fortis sp. nov., and A26 isolates in another, $V$. hepatarius sp. nov. Because several phylogenetic neighbours of $V$. fortis and $V$. hepatarius (i.e. V. neptunius,
$V$. brasiliensis, $V$. xuii and V. coralliilyticus) were analysed phenotypically and described by using the same methodologies as in this study, we assume that these results are largely comparable. Similar phenotypic methodologies have also been applied to the description of $V$. diabolicus (Raguénès et al., 1997), V. mytili (Pujalte et al., 1993) and the two novel species in this study, suggesting that comparisons may be reliable.

\section{Description of Vibrio fortis sp. nov.}

Vibrio fortis (for'tis. L. adj. fortis strong).

Cells are slightly curved, $1 \mu \mathrm{m}$ in width and $3 \mu \mathrm{m}$ in length. They form translucent to opaque, low convex, nonswarming, smooth-rounded colonies with entire margins that are beige in colour and about $4 \mathrm{~mm}$ in diameter on TSA after $48 \mathrm{~h}$ incubation at $28^{\circ} \mathrm{C}$. Strains form yellow and/or green, translucent, smooth-rounded colonies of 4-5 mm diameter on TCBS. All strains have a facultatively anaerobic metabolism and ferment glucose and mannitol,

Table 3. Features that diffentiate $V$. fortis and $V$. hepatarius from closely related Vibrio species

Taxa: 1, V. fortis ( $n=16)$; 2, V. hepatarius ( $n=3) ; 3, V$. neptunius (Thompson et al., 2003); 4, V. brasiliensis (Thompson et al., 2003); 5, V. xuii (Thompson et al., 2003); 6, V. pelagius (Alsina \& Blanch, 1994); 7, V. coralliilyticus (Ben-Haim et al., 2003); 8, V. diabolicus (Raguénès et al., 1997); 9, V. mytili (Pujalte et al., 1993); 10, V. nereis (Alsina \& Blanch, 1994); 11, V. orientalis (Alsina \& Blanch, 1994); 12, V. tubiashii (Alsina \& Blanch, 1994). Fatty acid data are given as mean \pm SD (\%). Abbreviations: +, positive; - , negative; V, variable feature (followed by type strain feature); ND, no data available. Utilization of gentiobiose, fermentation of amygdalin and melibiose, enzyme activities and fatty acid profiles of known Vibrio species are from our own database.

\begin{tabular}{|c|c|c|c|c|c|c|c|c|c|c|c|c|}
\hline Feature & 1 & 2 & 3 & 4 & 5 & 6 & 7 & 8 & 9 & 10 & 11 & 12 \\
\hline \multicolumn{13}{|l|}{ Production of: } \\
\hline Indole & + & + & + & + & + & - & + & + & - & $\mathrm{V}$ & + & + \\
\hline Acetoin & $\mathrm{v}+$ & + & + & + & + & - & - & - & - & - & - & - \\
\hline \multicolumn{13}{|l|}{ Utilization of: } \\
\hline Cellobiose & + & + & - & + & + & - & - & - & + & - & + & + \\
\hline D-Galactose & + & $\mathrm{v}+$ & - & + & - & + & + & + & + & - & + & + \\
\hline Gentiobiose & + & $\mathrm{v}-$ & - & + & $\mathrm{V}$ & $\mathrm{V}$ & - & - & + & - & ND & - \\
\hline Growth on $10 \%(\mathrm{w} / \mathrm{v}) \mathrm{NaCl}$ & $\mathrm{v}-$ & + & - & - & + & - & - & ND & + & + & + & $\mathrm{V}$ \\
\hline Nitrate reduction & $\mathrm{v}+$ & + & + & + & + & + & + & + & + & + & + & + \\
\hline \multicolumn{13}{|l|}{ Fermentation of: } \\
\hline Mannitol & + & + & - & + & + & + & - & + & + & - & + & + \\
\hline Amygdalin & $\mathrm{v}+$ & + & - & + & + & - & - & - & + & - & - & - \\
\hline Melibiose & $\mathrm{v}+$ & - & - & - & - & - & - & - & - & - & - & $\mathrm{V}$ \\
\hline \multicolumn{13}{|l|}{ Enzyme activity: } \\
\hline$\beta$-Galactosidase & $\mathrm{v}+$ & - & - & + & - & + & + & - & + & - & - & + \\
\hline Tryptophan deaminase & + & $\mathrm{v}+$ & + & - & + & - & - & + & + & - & - & - \\
\hline \multicolumn{13}{|l|}{ FAME composition: } \\
\hline iso- $\mathrm{C}_{14: 0}$ & $2 \cdot 7 \pm 1 \cdot 5$ & $1 \cdot 3 \pm 1 \cdot 1$ & $0 \cdot 2 \pm 0 \cdot 1$ & $3 \cdot 3 \pm 0 \cdot 4$ & $1 \cdot 2 \pm 0 \cdot 1$ & $2 \cdot 5$ & $0 \cdot 5$ & $0 \cdot 2$ & $0 \cdot 0$ & $0 \cdot 2$ & $0 \cdot 6$ & $0 \cdot 0$ \\
\hline iso- $\mathrm{C}_{14: 0} 3-\mathrm{OH}$ & $1 \cdot 1 \pm 0 \cdot 6$ & $0 \cdot 8 \pm 0 \cdot 6$ & $0 \cdot 1 \pm 0 \cdot 1$ & $1 \cdot 3 \pm 0 \cdot 2$ & $0 \cdot 9 \pm 0 \cdot 1$ & $1 \cdot 0$ & $0 \cdot 3$ & $0 \cdot 3$ & $0 \cdot 3$ & $0 \cdot 3$ & $0 \cdot 0$ & $0 \cdot 0$ \\
\hline $\mathrm{C}_{16: 0}$ & $18 \pm 7$ & $20 \cdot 0 \pm 2 \cdot 8$ & $18 \cdot 0 \pm 0 \cdot 8$ & $11 \cdot 3 \pm 0 \cdot 3$ & $12 \cdot 5 \pm 0 \cdot 6$ & 12 & 15 & $14 \cdot 4$ & $18 \cdot 8$ & $12 \cdot 9$ & $27 \cdot 6$ & $17 \cdot 3$ \\
\hline iso- $\mathrm{C}_{16: 0}$ & $8 \cdot 4 \pm 4 \cdot 3$ & $4 \cdot 8 \pm 3 \cdot 9$ & $0 \cdot 5 \pm 0 \cdot 1$ & $10 \cdot 5 \pm 0 \cdot 6$ & $5 \cdot 5 \pm 0 \cdot 4$ & $7 \cdot 5$ & $0 \cdot 8$ & $1 \cdot 7$ & $1 \cdot 5$ & $1 \cdot 1$ & $0 \cdot 0$ & $0 \cdot 0$ \\
\hline $\mathrm{C}_{17: 0}$ & $0.5 \pm 0.9$ & $0 \cdot 3 \pm 0 \cdot 1$ & $2 \cdot 3 \pm 0 \cdot 2$ & $0 \cdot 6 \pm 0 \cdot 1$ & $0 \cdot 5 \pm 0 \cdot 1$ & $0 \cdot 5$ & $2 \cdot 5$ & $1 \cdot 6$ & $0 \cdot 0$ & $1 \cdot 9$ & $0 \cdot 0$ & $0 \cdot 1$ \\
\hline $\mathrm{C}_{17: 1} \omega 8 c$ & $0 \cdot 7 \pm 1 \cdot 9$ & $0 \cdot 2 \pm 0 \cdot 2$ & $2 \cdot 1 \pm 0 \cdot 1$ & $0 \cdot 7 \pm 0 \cdot 1$ & $0 \cdot 5$ & $0 \cdot 5$ & $1 \cdot 8$ & $2 \cdot 5$ & $0 \cdot 0$ & $4 \cdot 6$ & $0 \cdot 0$ & $0 \cdot 1$ \\
\hline $\mathrm{C}_{17: 1} \omega 6 c$ & $0 \cdot 1 \pm 0 \cdot 1$ & $0 \cdot 0$ & $1 \cdot 2 \pm 0 \cdot 1$ & $0 \cdot 3 \pm 0 \cdot 1$ & $0 \cdot 2$ & $0 \cdot 0$ & $0 \cdot 6$ & $0 \cdot 7$ & $0 \cdot 0$ & $1 \cdot 3$ & $0 \cdot 0$ & $0 \cdot 0$ \\
\hline $\mathrm{C}_{18: 1} \omega 7 c$ & $11 \cdot 9 \pm 2 \cdot 9$ & $15 \cdot 5 \pm 0 \cdot 5$ & $17 \cdot 8 \pm 1 \cdot 6$ & $17 \cdot 3 \pm 0 \cdot 3$ & $21 \cdot 0 \pm 2 \cdot 4$ & 23 & $18 \cdot 2$ & $17 \cdot 4$ & $19 \cdot 9$ & $22 \cdot 6$ & $4 \cdot 3$ & $25 \cdot 4$ \\
\hline
\end{tabular}


but not inositol, sorbitol or rhamnose. Growth occurs at $4-35^{\circ} \mathrm{C}$ and in media that contain $1-8 \%(\mathrm{w} / \mathrm{v}) \mathrm{NaCl}$. Prolific growth occurs at $28{ }^{\circ} \mathrm{C}$ in media that contain $2 \cdot 5 \%(\mathrm{w} / \mathrm{v}) \mathrm{NaCl}$. The following features are positive for all strains: oxidase, catalase, $\beta$-galactosidase and tryptophan deaminase activities and indole production. All strains utilize dextrin, glycogen, Tween 40 , Tween $80, \mathrm{~N}$ acetyl-D-glucosamine, $\mathrm{N}$-acetyl-D-galactosamine, cellobiose, $\mathrm{D}$-fructose, D-galactose, gentiobiose, $\alpha$-D-glucose, maltose, D-mannitol, D-mannose, psicose, D-sorbitol, sucrose, D-trehalose, methyl pyruvate, monomethyl succinate, D-gluconic acid, DL-lactic acid, succinic acid, L-alanine, L-alanylglycine, L-asparagine, L-aspartic acid, L-glutamic acid, glycyl L-aspartic acid, glycyl L-glutamic acid, L-proline, L-serine, L-threonine, inosine, thymidine and glycerol as sole carbon sources. None of the strains can utilize adonitol, D-arabitol, $i$-erythritol, L-fucose, $m$-inositol, L-rhamnose, xylitol, citric acid, formic acid, D-galactonic acidolactone, D-glucuronic acid, $\alpha$-hydroxybutyric acid, $p$-hydroxyphenylacetic acid, itaconic acid, $\alpha$-ketobutyric acid, malonic acid, D-saccharic acid, sebacic acid, succinamic acid, glucuronamide, alaninamide, hydroxy L-proline, L-phenylalanine, L-pyroglutamic acid, DL-carnitine, urocanic acid, phenylethylamine, 2-aminoethanol, 2,3-butanediol or glucose 1-phosphate as sole carbon sources. The following tests are negative for all strains: arginine dihydrolase, lysine and ornithine decarboxylase activities, $\mathrm{H}_{2} \mathrm{~S}$ production and urease activity. The most abundant fatty acids are summed feature $3 \quad\left(37.5 \pm 2.9 \%\right.$; comprises $\mathrm{C}_{16: 1} \omega 7 c$ and/or iso- $\left.\mathrm{C}_{15: 0} 2-\mathrm{OH}\right), \mathrm{C}_{16: 0}(18 \cdot 0 \pm 7 \cdot 0 \%), \mathrm{C}_{18: 1} \omega 7 c$ $(11 \cdot 9 \pm 2 \cdot 9 \%)$, iso- $\mathrm{C}_{16: 0}(8 \cdot 4 \pm 4 \cdot 3 \%), \mathrm{C}_{14: 0}(5 \cdot 3 \pm 1 \cdot 4 \%)$, $\mathrm{C}_{12: 0}(3 \cdot 6 \pm 1 \cdot 2 \%)$, iso- $\mathrm{C}_{14: 0} \quad(2 \cdot 7 \pm 1 \cdot 5 \%)$, summed feature $2\left(2 \cdot 4 \pm 0 \cdot 4 \%\right.$; comprises $\mathrm{C}_{14: 0} 3-\mathrm{OH}$ and/or iso$\mathrm{C}_{16: 1} \mathrm{I}$ and/or unidentified fatty acid with equivalent chain-length value of 10.928 and/or $\left.\mathrm{C}_{12: 0} \mathrm{ALDE}\right), \mathrm{C}_{12: 0}$ $3-\mathrm{OH}(1 \cdot 5 \pm 0 \cdot 4 \%), \mathrm{C}_{18: 0}(1 \cdot 2 \pm 0 \cdot 6 \%)$, iso- $\mathrm{C}_{14: 0} 3-\mathrm{OH}$ $(1 \cdot 1 \pm 0 \cdot 6 \%), \mathrm{C}_{17: 1} \omega 8 c(0 \cdot 7 \pm 1 \cdot 9 \%)$, unknown $12 \cdot 484$ $(0 \cdot 6 \pm 0 \cdot 2 \%)$, iso- $\mathrm{C}_{18: 0}(0 \cdot 6 \pm 0 \cdot 3 \%), \mathrm{C}_{15: 0}(0 \cdot 6 \pm 1 \cdot 2 \%)$, $\mathrm{C}_{17: 0}(0 \cdot 5 \pm 0 \cdot 9 \%)$, iso- $\mathrm{C}_{12: 0} \quad(0 \cdot 4 \pm 0 \cdot 2 \%)$, summed feature $7 \quad\left(0 \cdot 4 \pm 0.2 \%\right.$; comprises $\mathrm{C}_{19: 1} \omega 6 c$ and/or unidentified fatty acid with equivalent chain-length value of 18.846), iso- $\mathrm{C}_{12: 0} 3-\mathrm{OH}(0 \cdot 3 \pm 0 \cdot 2 \%), \mathrm{C}_{15: 1} \omega 8 c$ $(0.3 \pm 0.9 \%), \quad \mathrm{C}_{20: 1} \omega 7 c \quad(0 \cdot 2 \pm 0 \cdot 1 \%), \quad \mathrm{C}_{16: 1} \omega 5 c$ $(0 \cdot 2 \pm 0 \cdot 1 \%), \mathrm{C}_{16: 1} \omega 7 c$ alcohol $(0 \cdot 2 \pm 0 \cdot 1 \%)$, unknown $11 \cdot 799(0 \cdot 2 \pm 0 \cdot 1 \%), \mathrm{C}_{18: 1} \omega 5 c(0 \cdot 1 \pm 0 \cdot 1 \%), \mathrm{C}_{11: 0} 3-\mathrm{OH}$ $(0 \cdot 1 \pm 0 \cdot 5 \%), \mathrm{C}_{10: 0} \quad 3-\mathrm{OH}(0 \cdot 1 \pm 0 \cdot 4 \%), \mathrm{C}_{12: 0} \quad 2-\mathrm{OH}$ $(0 \cdot 1 \pm 0 \cdot 0 \%), \quad \mathrm{C}_{16: 0} \quad 3-\mathrm{OH} \quad(0 \cdot 1 \pm 0 \cdot 3 \%), \quad 11$-methyl $\mathrm{C}_{18: 1} \omega 7 c(0 \cdot 1 \pm 0 \cdot 1 \%)$, anteiso- $\mathrm{C}_{17: 0}(0 \cdot 1 \pm 0 \cdot 3 \%), \mathrm{C}_{13: 0}$ $(0 \cdot 1 \pm 0 \cdot 2 \%)$ and $\mathrm{C}_{17: 1} \omega 6 c(0 \cdot 1 \pm 0 \cdot 1 \%)$. All strains are susceptible to tetracycline $(30 \mu \mathrm{g})$ and chloramphenicol $(30 \mu \mathrm{g})$, but are moderately resistant to polymyxin $(300 \mathrm{U})$. Additional phenotypic features are listed in Supplementary Table A in IJSEM Online. 16S rDNA sequences of strains LMG $21557^{\mathrm{T}}$, LMG 21558, LMG 20547, LMG 21566 and LMG 21562 are deposited in GenBank/EMBL under accession numbers AJ514916, AJ514913, AJ316202, AJ514917 and AJ514915, respectively. DNA G + C content of the type strain is $45 \cdot 6 \mathrm{~mol} \%$.
The type strain of this species, LMG $21557^{\mathrm{T}}$ (=CAIM $629^{\mathrm{T}}$ ), was isolated from the white shrimp Litopenaeus vannamei in Ecuador.

\section{Description of Vibrio hepatarius sp. nov.}

Vibrio hepatarius (he.pa.ta'ri.us. L. masc. adj. hepatarius of or belonging to the liver).

Cells are slightly curved, $1 \mu \mathrm{m}$ in width and $2-3 \mu \mathrm{m}$ in length. They form translucent, convex, non-swarming, smooth-rounded colonies with entire margins that are beige in colour and about $6 \mathrm{~mm}$ in diameter on TSA after $48 \mathrm{~h}$ incubation at $28^{\circ} \mathrm{C}$. Strains form yellow, translucent, smooth-rounded colonies of $6 \mathrm{~mm}$ diameter on TCBS. All strains have a facultatively anaerobic metabolism and ferment glucose, mannitol, sucrose and amygdalin, but not inositol, rhamnose, melibiose or arabinose. Growth occurs at $4-35^{\circ} \mathrm{C}$ and in media that contain $0-8 \%(\mathrm{w} / \mathrm{v})$ $\mathrm{NaCl}$. Prolific growth occurs at $28^{\circ} \mathrm{C}$ in media that contain $2.5 \%(\mathrm{w} / \mathrm{v}) \mathrm{NaCl}$. The following tests are positive for all strains: oxidase and catalase activities, indole and acetoin production and $\mathrm{NO}_{3}$ reduction. All strains utilize dextrin, $N$-acetyl-D-glucosamine, cellobiose, D-fructose, $\alpha$-D-glucose, maltose, psicose, sucrose, D-trehalose, methyl pyruvate, inosine and glycerol as sole carbon sources. None of the strains can utilize glycogen, Tween $40, \mathrm{~N}$-acetyl-D-galactosamine, adonitol, L-arabinose, D-arabitol, i-erythritol, L-fucose, D-galactose, gentiobiose, $m$-inositol, $\alpha$-lactose, $\alpha$-D-lactose lactulose, D-melibiose, D-raffinose, L-rhamnose, turanose, xylitol, monomethyl succinate, acetic acid, cis-aconitic acid, citric acid, formic acid, D-galactonic acidolactone, D-galacturonic acid, D-gluconic acid, D-glucosaminic acid, D-glucuronic acid, $\alpha$-hydroxybutyric acid, $\gamma$-hydroxybutyric acid, $p$-hydroxyphenylacetic acid, itaconic acid, $\alpha$-ketobutyric acid, $\alpha$-ketovaleric acid, malonic acid, propionic acid, quinic acid, D-saccharic acid, sebacic acid, bromosuccinic acid, succinamic acid, glucuronamide, alaninamide, D-alanine, L-aspartic acid, glycyl L-aspartic acid, glycyl L-glutamic acid, L-histidine, hydroxy L-proline, L-leucine, L-ornithine, L-phenylalanine, L-pyroglutamic acid, D-serine, L-threonine, DL-carnitine, $\gamma$-aminobutyric acid, urocanic acid, uridine, thymidine, phenylethylamine, putrescine, 2-aminoethanol, 2,3-butanediol, DL- $\alpha$-glycerol phosphate, glucose 1-phosphate or glucose 6-phosphate as sole carbon sources. The following tests are negative for all strains: $\beta$-galactosidase, lysine and ornithine decarboxylases, $\mathrm{H}_{2} \mathrm{~S}$ production and urease. The most abundant fatty acids are summed feature $3\left(28 \cdot 4 \pm 15 \cdot 2 \%\right.$; comprises $\mathrm{C}_{16: 1} \omega 7 c$ and/or iso- $\left.\mathrm{C}_{15: 0} 2-\mathrm{OH}\right), \mathrm{C}_{16: 0}(14 \cdot 6 \pm 9 \cdot 6 \%)$, iso- $\mathrm{C}_{15: 0}$ $(13 \cdot 2 \pm 22 \cdot 1 \%), \mathrm{C}_{18: 1} \omega 7 c(10 \cdot 3 \pm 9 \cdot 9 \%), \mathrm{C}_{14: 0}(5 \cdot 4 \pm 1 \cdot 4 \%)$, iso- $\mathrm{C}_{16: 0}(4 \cdot 7 \pm 2 \cdot 7 \%)$, iso- $\mathrm{C}_{13: 0}(3 \cdot 7 \pm 5 \cdot 4 \%)$, iso- $\mathrm{C}_{17: 0}$ $(2 \cdot 5 \pm 3 \cdot 7 \%), \mathrm{C}_{12: 0}(2 \cdot 2 \pm 1 \cdot 9 \%)$, summed feature 2 $\left(2 \cdot 2 \pm 0 \cdot 3 \%\right.$; comprises $\mathrm{C}_{14: 0} 3-\mathrm{OH}$ and/or iso- $\mathrm{C}_{16: 1} \mathrm{I}$ and/or unidentified fatty acid with equivalent chainlength value of 10.928 and/or $\mathrm{C}_{12: 0} \mathrm{ALDE}$ ), iso- $\mathrm{C}_{14: 0}$ $(2 \cdot 0 \pm 1 \cdot 4 \%)$, anteiso- $\mathrm{C}_{15: 0}(1.9 \pm 2.9 \%), \mathrm{C}_{12: 0} 3-\mathrm{OH}$ $(1 \cdot 1 \pm 1 \cdot 0 \%)$, iso- $\mathrm{C}_{17: 1} \omega 5 c(1 \cdot 1 \pm 1 \cdot 9 \%)$, iso- $\mathrm{C}_{17: 1} \omega 10 c$ $(0 \cdot 8 \pm 1 \cdot 4 \%)$, unknown $12 \cdot 484(0 \cdot 5 \pm 0 \cdot 5 \%)$, iso- $\mathrm{C}_{14: 0}$ 
$3-\mathrm{OH}(0 \cdot 5 \pm 0 \cdot 6 \%)$, anteiso- $\mathrm{C}_{17: 0}(0 \cdot 5 \pm 0 \cdot 6 \%)$, anteiso$\mathrm{C}_{13: 0}(0 \cdot 5 \pm 0 \cdot 8 \%), \mathrm{C}_{16: 1} \omega 7 c$ alcohol $(0 \cdot 4 \pm 0 \cdot 6 \%), \mathrm{C}_{15: 0}$ $(0 \cdot 4 \pm 0 \cdot 4 \%), \mathrm{C}_{17: 0}(0 \cdot 2 \pm 0 \cdot 2 \%)$ and $\mathrm{C}_{17: 1} \omega 8 c(0 \cdot 1 \pm$ $0 \cdot 2 \%)$. All strains are susceptible to the vibriostatic agent $\mathrm{O} / 129$ (10 and $150 \mu \mathrm{g}$ ), polymyxin (300 U), tetracycline $(30 \mu \mathrm{g})$ and chloramphenicol $(30 \mu \mathrm{g})$, but are moderately resistant to ampicillin $(25 \mu \mathrm{g})$. Additional phenotypic features are listed in Supplementary Table B in IJSEM Online. The $16 \mathrm{~S}$ rDNA sequence of strain LMG $20362^{\mathrm{T}}$ is deposited in GenBank/EMBL under accession number AJ345063. DNA G+C content of the type strain is $45 \cdot 5 \mathrm{~mol} \%$.

The type strain of this species, LMG $20362^{\mathrm{T}}$ (=CAIM $693^{\mathrm{T}}$ ), was isolated from the white shrimp Litopenaeus vannamei in Ecuador.

\section{ACKNOWLEDGEMENTS}

F. L. T. has a PhD scholarship (no. 2008361/98-6) from Conselho Nacional de Desenvolvimento Científico e Tecnológico (CNPq), Brazil. J.S. acknowledges grants from the Fund for Scientific Research (FWO), Belgium. The authors acknowledge Professor P. Vandamme for helping with the nomenclature of the novel species. The authors also acknowledge the suggestions of the two reviewers.

\section{REFERENCES}

Acar, J. F. \& Goldstein, F. W. (1996). Disc susceptibility test. In Antibiotics in Laboratory Medicine, 4th edn, pp. 1-51. Edited by V. Lorian. Baltimore: Williams \& Wilkins.

Alsina, M. \& Blanch, A. R. (1994). A set of keys for biochemical identification of environmental Vibrio species. J Appl Bacteriol 76, 79-85.

Baumann, P., Furniss, A. L. \& Lee, J. V. (1984). Genus I. Vibrio Pacini 1854. In Bergey's Manual of Systematic Bacteriology, vol. 1, pp. 518-538. Edited by N. R. Krieg \& J. G. Holt. Baltimore: Williams \& Wilkins.

Ben-Haim, Y., Thompson, F. L., Thompson, C. C., Cnockaert, M. C., Hoste, B., Swings, J. \& Rosenberg, E. (2003). Vibrio coralliilyticus sp. nov., a temperature-dependent pathogen of the coral Pocillopora damicornis. Int J Syst Evol Microbiol 53, 309-315.

Bertone, S., Giacomini, M., Ruggiero, C., Piccarolo, C. \& Calegari, L. (1996). Automated systems for identification of heterotrophic marine bacteria on the basis of their fatty acid composition. Appl Environ Microbiol 62, 2122-2132.

Farmer, J. J., III \& Hickman-Brenner, F. W. (1992). The genera Vibrio and Photobacterium. In The Prokaryotes. A Handbook on the Biology of Bacteria: Ecophysiology, Isolation, Identification, Applications, 2nd edn, pp. 2952-3011. Edited by A. Balows, H. G. Trüper, M. Dworkin, W. Harder \& K. H. Schleifer. New York: Springer-Verlag.

Gomez-Gil, B., Tron-Mayén, L., Roque, A., Turnbull, J. F., Inglis, V. \& Guerra-Flores, A. L. (1998). Species of Vibrio isolated from hepatopancreas, haemolymph and digestive tract of a population of healthy juvenile Penaeus vannamei. Aquaculture 163, 1-9.

Gomez-Gil, B., Roque, A. \& Turnbull, J. F. (2000). The use and selection of probiotic bacteria for use in the culture of larval aquatic organisms. Aquaculture 191, 259-270.
Gomez-Gil, B., Roque, A. \& Velasco-Blanco, G. (2002). Culture of Vibrio alginolyticus $\mathrm{C} 7 \mathrm{~b}$, a potential probiotic bacterium, with the microalga Chaetoceros muelleri. Aquaculture 211, 43-48.

Heidelberg, J. F., Heidelberg, K. B. \& Colwell, R. R. (2002a). Seasonality of Chesapeake Bay bacterioplankton species. Appl Environ Microbiol 68, 5488-5497.

Heidelberg, J. F., Heidelberg, K. B. \& Colwell, R. R. (2002b). Bacteria of the $\gamma$-subclass Proteobacteria associated with zooplankton in Chesapeake Bay. Appl Environ Microbiol 68, 5498-5507.

Huys, G., Vancanneyt, M., Coopman, R., Janssen, P., Falsen, E., Altwegg, M. \& Kertsers, K. (1994). Cellular fatty acid composition as a chemotaxonomic marker for the differentiation of phenospecies and hybridization groups in the genus Aeromonas. Int J Syst Bacteriol 44, 651-658.

Jukes, T. H. \& Cantor, C. R. (1969). Evolution of protein molecules. In Mammalian Protein Metabolism, pp. 21-132. Edited by $\mathrm{H}$. N. Munro. New York: Academic Press.

Lambert, M. A., Hickman-Brenner, F. W., Farmer, J. J., III \& Moss, C. W. (1983). Differentiation of Vibrionaceae species by their cellular fatty acid composition. Int J Syst Bacteriol 33, 777-792.

Lipp, E. K., Huq, A. \& Colwell, R. R. (2002). Effects of global climate on infectious disease: the cholera model. Clin Microbiol Rev 15, 757-770.

Macián, M. C., Ludwig, W., Schleifer, K.-H., Garay, E. \& Pujalte, M. J. (2000). Vibrio pelagius: differences of the type strain deposited at various culture collections. Syst Appl Microbiol 23, 373-375.

Mesbah, M., Premachandran, U. \& Whitman, W. B. (1989). Precise measurement of the $\mathrm{G}+\mathrm{C}$ content of deoxyribonucleic acid by highperformance liquid chromatography. Int J Syst Bacteriol 39, 159-167.

Moss, S. M., LeaMaster, B. R. \& Sweeney, J. N. (2000). Relative abundance and species composition of gram-negative, aerobic bacteria associated with the gut of juvenile white shrimp Litopenaeus vannamei reared in oligotrophic well water and eutrophic pond water. J World Aquac Soc 31, 255-263.

Pitcher, D. G., Saunders, N. A. \& Owen, R. J. (1989). Rapid extraction of bacterial genomic DNA with guanidium thiocyanate. Lett Appl Microbiol 8, 151-156.

Pujalte, M. J., Ortigosa, M., Urdaci, M.-C., Garay, E. \& Grimont, P. A. D. (1993). Vibrio mytili sp. nov., from mussels. Int J Syst Bacteriol 43, 358-362.

Raguénès, G., Christen, R., Guezennec, J., Pignet, P. \& Barbier, G. (1997). Vibrio diabolicus sp. nov., a new polysaccharide-secreting organism isolated from a deep-sea hydrothermal vent polychaete annelid, Alvinella pompejana. Int J Syst Bacteriol 47, 989-995.

Ruimi, R., Breittmayer, V., Elbaze, P., Lafay, B., Boussemart, O., Gauthier, M. \& Christen, R. (1994). Phylogenetic analysis and assessment of the genera Vibrio, Photobacterium, Aeromonas, and Plesiomonas deduced from small-subunit rRNA sequences. Int J Syst Bacteriol 44, 416-426.

Saitou, N. \& Nei, M. (1987). The neighbor-joining method: a new method for reconstructing phylogenetic trees. Mol Biol Evol 4, 406-425.

Thompson, F. L., Hoste, B., Vandemeulebroecke, K. \& Swings, J. (2001). Genomic diversity amongst Vibrio isolates from different sources determined by fluorescent amplified fragment length polymorphism. Syst Appl Microbiol 24, 520-538.

Thompson, F. L., Hoste, B., Vandemeulebroecke, K., Engelbeen, K., Denys, R. \& Swings, J. (2002). Vibrio trachuri Iwamoto et al. 1995 is a junior synonym of Vibrio harveyi (Johnson and Shunk 1936) Baumann et al. 1981. Int J Syst Evol Microbiol 52, 973-976.

Thompson, F. L., Li, Y., Gomez-Gil, B. \& 8 other authors (2003). Vibrio neptunius sp. nov., Vibrio brasiliensis sp. nov. and Vibrio xuii 
sp. nov., isolated from the marine aquaculture environment (bivalves, fish, rotifers and shrimps). Int J Syst Evol Microbiol 53, 245-252.

Vandamme, P., Segers, P., Ryll, M. \& 8 other authors (1998). Pelistega europaea gen. nov., sp. nov., a bacterium associated with respiratory disease in pigeons: taxonomic structure and phylogenetic allocation. Int J Syst Bacteriol 48, 431-440.

Vandenberghe, J., Verdonck, L., Robles-Arozarena, R. \& 7 other authors (1999). Vibrios associated with Litopenaeus vannamei larvae, postlarvae, broodstock, and hatchery probionts. Appl Environ Microbiol 65, 2592-2597.

Verschuere, L., Rombaut, G., Sorgeloos, P. \& Verstraete, W. (2000). Probiotic bacteria as biological control agents in aquaculture. Microbiol Mol Biol Rev 64, 655-671.

Willems, A., Doignon-Bourcier, F., Goris, J., Coopman, R., de Lajudie, P., De Vos, P. \& Gillis, M. (2001). DNA-DNA hybridization study of Bradyrhizobium strains. Int $J$ Syst Evol Microbiol 51, 1315-1322. 